
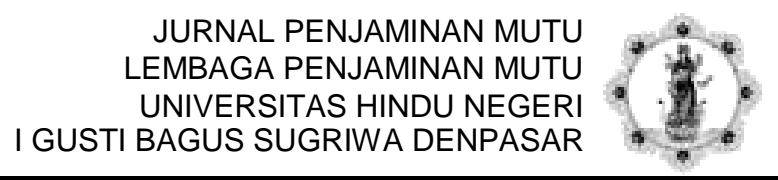

Volume 7 Nomor 22021

ISSN : 2407-912X (Cetak)

ISSN : 2548-3110 (Online)

http://ejournal.ihdn.ac.id/index.php/JPM

\title{
EVALUATING ONLINE LEARNING IMPLEMENTATION IN TEACHER EDUCATION DURING COVID-19 PANDEMIC; A QUALITY ASSURANCE CYCLE
}

\author{
Oleh \\ Ahmad Syafi'i \\ STKIP Al Hikmah Surabaya \\ ahmadsyafii20@gmail.com
}

diterima 01 Maret 2021, direvisi 26 Juni 2021, diterbitkan 31 Agustus 2021

\begin{abstract}
Abstrack
The purpose of this study is to report the results of the analysis of monitoring and evaluating the implementation of lectures or Learning from Home (BDH) at STKIP Al Hikmah Surabaya in the even semester of the 2019/2020 academic year. The subjects of this study were 33 lecturers from 5 study programs at STKIP Al Hikmah Surabaya. This study uses a qualitative descriptive research design. The research instrument used is a daily lecture monitoring and evaluation questionnaire that must be filled out by all lecturers on the course campus. The results of this study are grouped into 5 major aspects, namely: 1) the application of lectures that are most often used by lecturers, 2) the lecture activities that are most often carried out, 3) the level of structured assignment collection, 4) the level of student participation in lectures, 5) the obstacles/challenges that arise. most often faced by lecturers in bold learning.
\end{abstract}

\section{Keyword : Monitoring, Evaluation, Online Lectures, Teacher Campuses, Covid-19}

\section{INTRODUCTION}

The outbreak of Covid-19 has seriously altered the paradigm and practices of teaching and learning in every level of education. Face to face classroom traditionally practiced shifted into online learning due to health consideration (Alqahtani \& Rajkhan, 2020). It subsequently drives schools or universities to redesign practices of teaching and learning into IT based teaching and learning practices(Allo, 2020). It is in line with the policy issued by The Ministry of Education and Culture that instructed schools and other educational institutions including higher education to temporarily redesign the practices of traditional teaching and learning or so called face to face instruction into online learning (Irfan et al., 2020). He also added that online learning has become one of the most effective alternative solution regardless strengths and weaknesses. He pointed out that 
online learning is more practical in term of time and place.

On the other hand, online learning is potentially raises a very serious problem relating to signal strength, incompatible device and plagiarism (Arkorful \& Abaidoo, 2015). Despite its practicality, this change subsequently raises several problems (Hung\&Chou, 2015). Less experience of how to utilize online application could be the major problem acquainted by lecturer (Orkin, 1996).

Several research investigating the implementation of online learning (Maarop \& Embi, 2016), (Fauzi \& Sastra Khusuma, 2020), (Aboagye et al., 2020), (Chang \& Fang, 2020), (Hoq, 2020), (Irfan et al., 2020). However, most of studies conducted in higher education or tertiary education. This study was particularly conducted in teacher higher education. The researcher focused on five aspects namely 1) online learning applications frequently used by the lecturers 2) online learning activities frequently conducted by the lecturers, 3) task submission rate, 4) students' participation rate and 5) challenges experienced by the lecturers during the online learning and alternative solutions proposed by the lecturers.

The findings of this study are expected to broaden our insight towards the implementation of online learning particularly in teacher higher education and also assist teacher higher education administrator to design the best practice in teacher higher education. The researcher also expected that the findings would be followed up by other researcher to formulate the best practice of the implementation of online learning particularly in teacher higher education.

\section{METHOD \\ Research Design}

This study used a quantitative approach. (Creswell, 2007) explained that the quantitative approach is a measurement of data carried out in quantitative and objective statistics through scientific calculations derived from a sample of people or residents who are asked to answer questions about the survey to determine the frequency and percentage of their responses. The method used is the survey method. (Yuliansyah, 2013) mentioned that the survey is one method used to gather information about a group of people or phenomena that occur in the social environment. Survey research is very suitable to be used by researchers in revealing the implementation of online learning in teacher higher education during COVID-19 pandemic.

\section{Research Participant}

The participants in this study were 33 lecturers of five departments in STKIP Al Hikmah Surabaya who teaching in even semester 2019/2020 academic year.

\section{Research Instrument}

The sole instrument used in this study was an online daily teaching monitoring and evaluation questionnaire. It consists of 13 items. The questionnaire was made in a google form consisting of both open and closed items so that it was easily accessed and filled out by the lecturer after teaching his or her class.

\section{Data Collection and Analysis}

Data analysis in this study was conducted as follows, 1) open questionnaire analyzed based on inductive content analysis, according to (Mayring, 2015) that this content analysis produce response categories based on the coding process of free answers that have been submitted to respondents, this content analysis includes (a) open coding, at this stage the researcher provides notes of the various responses that arise from the respondent, (b) make categorization, researchers do grouping by making categorization based on the themes that emerge, and (c) make an abstraction, at this stage the researcher makes a general description based on the categories that have been obtained. After the content analysis process is done, the response is calculated using descriptive statistics (percentage), then the results are analyzed in detail, and 2) closed questionnaire is calculated using descriptive statistics (percentage) and the results are analyzed in detail. 


\section{RESULT AND DISCUSSION}

The teaching monitoring and evaluation questionnaire was given and filled out by lecturers after finishing teaching during the even semester in 2019/2020 academic year. The result of this study is categorized into five aspects namely 1) online learning applications frequently used by the lecturers 2) online learning activities frequently conducted by the lecturers 3) task submission rate, 4) students' participation rate and 5) challenges experienced by the lecturers during the online learning.

\section{1) Online learning applications} frequently used by the lecturers.

The online learning application or so called learning management system (LMS) most frequently used by the lecturers are WhatsApp (90.8\%0, Schoology (63.1\%), Google Classroom (22.7\%), Zoom Cloud Meeting (20.7\%) and Email (14.4\%) and others. WhatsApp becomes the most frequent application in online learning (Widiyono, 2020). (Salem M. Alqahtani et al., 2018) pointed that WhatsApp facilitate realtime communication between teachers and students, allowing students to persist in learning even beyond the classroom. In addition to, its features motivate students to connect and correspond in any language and person in the world. (Eko Yulianto et al., 2020) added that WhatsApp is more economical in data and student friendly. The more detailed information relating to online learning applications or so called learning management system (LMS) is represented in the following chart.

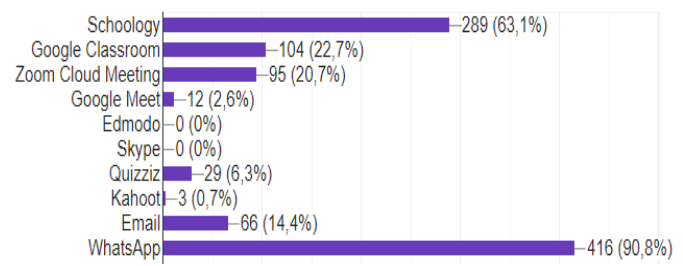

Figure 1. Online learning applications most frequently used by lecturers

2) Online learning activities frequently conducted by the lecturers
Online learning activities frequently conducted by the lecturers are discussion forum (79.9\%). (Moloudi, 2010) stated that online discussion forums increase the opportunities for student participation and enhance the participation of students who may feel inhibited when required to engage in discussions in a traditional classroom setting. The next learning activity is uploading assignment $(68.8 \%)$, uploading materials, conducting quizzes (24.2\%) and video conferences $(21.8 \%)$, and others.

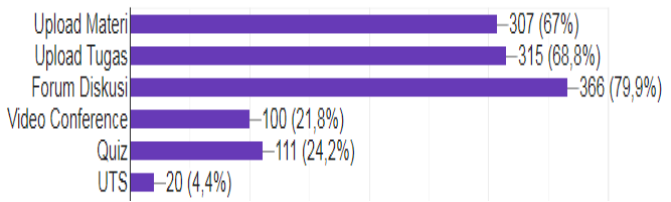

Figure 2. Online learning activities frequently conducted by the lecturers

\section{3) Task submission rate}

Structured task or so called portfolios are delivered during the online learning. The submission rate of punctual structured tasks or portfolios reached $64 \%$. The rate was not quite satisfying. Various problems led this finding. Network problem and incompatible device would be the most significant factors led into this finding. (Riyanda et al., 2020) highlighted in his reserach bad internet signal has become the most significant factor in the process of online learning.

\section{4) Students' participation rate}

Students' participation rate during the implementation of online learning Participation could be the major problem in online learning. The students' participation during online learning during Covid-19 pandemic reached 66\%. The rate was not satisfactorily good. The major cause led into low rate of student participation is internet signal. It is in line with (Ernawati et al., 2020) who stated that bad internet signal seriously influence student learning time.

5) Challenges experienced by the lecturers during the online learning 
Challenges experienced by the lecturers during the online learning are 1) students' social and psychological background $(33.2 \%)$. It is supported by (Sharpe, Rhona \& Benfield, 2005) investigated the students' experience of online learning at Oxford Brokes University. They highlighted some major problems experienced by students during online learning namely emotionality of the student experience and concern about time and time management, network problem $(24.9 \%)$. It is in line with (Aboagye et al., 2020) who revealed that accessibility is the most important challenge students are facing in a complete online learning situation. In addition to(Fauzi \& Sastra Khusuma, 2020) found out that network and internet usage is classified into major problem in online learning, and incompatible devices $(5.2 \%)$. Each of problems is represented in the following chart.

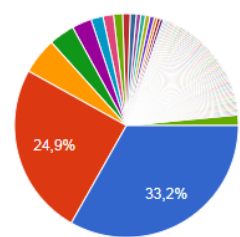

- Satu mahasiswa tidak ikut UTS karer - Tidy ada kendala - Kuota yang terbatas, sinyal di lokasi. - Mahasiswa terkendala jaringan yg tí Sejumlah mhs tidak bisa akses schor - jaringan mahasiswa untuk joint zoo - Jaringan internet terkadang naik turu - Sinyal di daerah mhs, habis absen,

A $3 / 13 \mathbf{\nabla}$

Figure 3. Challenges experienced by the lecturers during the online learning

Henceforth, the alternative solutions of those aforementioned problems are represented as follows: 1) providing alternative platforms, 2) phoning the students, 3) providing manual assignment, 4) changing the internet provider, and others. It is in line with (Asmuni, 2020) who proposed several alternative solutions as follows:1) preparing interesting teaching materials, 2) providing more accesible learning platforms, 3) actively inviting students to join the class and facilitating hard copy learning materials for those who have no internet access.

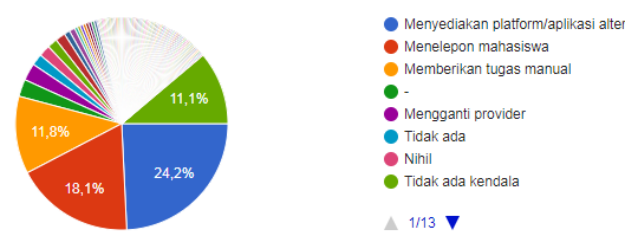

Figure 4. alternative solution conducted by the lecturers during the online learning conclusion

\section{CONCLUSION}

Based on the data presentation and research finding and discussion, it can be elaborated that online learning application or so called learning management system (LMS) most frequently used by the lecturers are WhatsApp (90.8\%0, Schoology (63.1\%), Google Classroom (22.7\%), Zoom Cloud Meeting (20.7\%) and Email (14.4\%) and others. Online learning activities frequently conducted by the lecturers are discussion forum $(79.9 \%)$, uploading assignment (68.8\%), uploading materials, conducting quizzes $(24.2 \%)$ and video conferences (21.8\%), and others. Structured task or so called portfolios are delivered during the online learning. The submission rate of punctual structured tasks or portfolios reached $64 \%$. The students' participation during online learning during Covid-19 pandemic reached $66 \%$.

The challenges experienced by the lecturers during the online learning are 1) students' social and psychological background $(33.2 \%)$. It is supported by (Sharpe, Rhona \& Benfield, 2005) investigated the students' experience of online learning at Oxford Brokes University. They highlighted some major problems experienced by students during online learning namely emotionality of the student experience and concern about time and time management, network problem $(24.9 \%)$. It is in line with (Aboagye et al., 2020) who revealed that accessibility is the most important challenge students are facing in a complete online learning situation. In addition to(Fauzi \& Sastra Khusuma, 2020) found out that network and internet usage is classified into major problem in online learning, and incompatible devices (5.2\%). 


\section{REFERENCE}

Aboagye, E., Yawson, J. A., \& Appiah, K. N. (2020). COVID-19 and E-Learning: the Challenges of Students in Tertiary Institutions. Social Education Research, 2(1), 109-115. http://ojs.wiserpub.com/index.php/SE R/article/view/422

Allo, M. D. G. (2020). Is the online learning good in the midst of Covid-19 Pandemic? The case of EFL learners. Jurnal Sinestesia, 10(1), 1-10.

Alqahtani, A. Y., \& Rajkhan, A. A. (2020). Elearning critical success factors during the covid-19 pandemic: A comprehensive analysis of e-learning managerial perspectives. Education Sciences, $\quad 10(9), \quad 1-16$. https://doi.org/10.3390/educsci10090 216

Arkorful, V., \& Abaidoo, N. (2015). The role of e-learning, advantages and disadvantages of its adoption in higher education. International Journal of Instructional Technology and Distance Learning, 12(1), 29-42.

Asmuni, A. (2020). Problematika Pembelajaran Daring di Masa Pandemi Covid-19 dan Solusi Pemecahannya. Jurnal Paedagogy, 7(4), 281. https://doi.org/10.33394/jp.v7i4.2941

Chang, C. L., \& Fang, M. (2020). E-Learning and Online Instructions of Higher Education during the 2019 Novel Coronavirus Diseases (COVID-19) Epidemic. Journal of Physics: Conference Series, 1574(1). https://doi.org/10.1088/17426596/1574/1/012166

Creswell, J. W. (2007). Research Design: Qualitative, Quantitative and Mixed Method Aproaches. SAGE Publications. https://doi.org/10.4135/97818492089 $\underline{56}$

Eko Yulianto, Putri Dwi Cahyani, \& Sofia Silvianita. (2020). Perbandingan Kehadiran Sosial dalam Pembelajaran Daring Menggunakan Whatsapp groupdan Webinar Zoom Berdasarkan Sudut Pandang Pembelajar Pada Masa Pandemic COVID-19. JARTIKA Jurnal Riset Teknologi Dan Inovasi Pendidikan, 3(2), 331-341. https://doi.org/10.36765/jartika.v3i2. $\underline{277}$

Ernawati, Y., Universitas, D., \& Darma, B. (2020). Problematik Pembelajaran Daring. 13(1), 1-15.

Fauzi, I., \& Sastra Khusuma, I. H. (2020). Teachers' Elementary School in Online Learning of COVID-19 Pandemic Conditions. Jurnal Iqra': Kajian Ilmu Pendidikan, 5(1), 58-70. https://doi.org/10.25217/ji.v5i1.914

Hoq, M. Z. (2020). E-Learning During the Period of Pandemic (COVID-19) in the Kingdom of Saudi Arabia: An Empirical Study. American Journal of Educational Research, 8(7), 457-464. https://doi.org/10.12691/education-87-2

Irfan, M., Kusumaningrum, B., Yulia, Y., \& Widodo, S. A. (2020). Challenges During the Pandemic: Use of ELearning in Mathematics Learning in Higher Education. Infinity Journal, 9(2), 147. https://doi.org/10.22460/infinity.v9i2. p147-158

Maarop, A. H., \& Embi, M. A. (2016). Implementation of Blended Learning in Higher Learning Institutions: A Review of Literature. International Education Studies, 9(3), 41. https://doi.org/10.5539/ies.v9n3p41

Mayring, P. (2015). Qualitative Content Analysis: Theoretical Background and Procedures.

https://doi.org/10.1007/978-94-0179181-6_13

Moloudi, M. (2010). Engagement With and Participation in Online Discussion. 12(2), 97-105.

Orkin, F. K. (1996). Ambulatory anesthesia: Past, present, and future. Anesthesiology Clinics of North America, 14(4), 595-608. 
https://doi.org/10.1016/S0889-

8537(05)70296-0

Riyanda, A. R., Herlina, K., \& Wicaksono, B.

A. (2020). Evaluasi Implementasi

Sistem Pembelajaran Daring Fakultas

Keguruan dan Ilmu Pendidikan

Universitas Lampung. Jurnal IKRA-

ITH Humaniora, 4(1), 66-71.

https://journals.upi-

yai.ac.id/index.php/ikraith-

humaniora/article/view/669

Salem M. Alqahtani, M., Bhaskar, C. V., Vadakalur Elumalai, K., \& Abumelha, M. (2018). WhatsApp: An Online Platform for University-Level English Language Education. Arab World English Journal, 9(4), 108-121. https://doi.org/10.24093/awej/vol9no 4.7

Sharpe, Rhona \& Benfield, G. (2005). Brookes e Journal of Learning and Teaching The Student Experience of E-learning in Higher Education: A Review of the Literature. Brookes EJournal of Learning and Teaching.

Widiyono, A. (2020). Efektifitas Perkuliahan Daring (Online) pada Mahasiswa PGSD di Saat Pandemi Covid 19. Jurnal Pendidikan, 8(2), 169-177. https://doi.org/10.36232/pendidikan.v $8 \mathrm{i} 2.458$

Yuliansyah. (2013). Meningkatkan response rate pada penelitian survey. In Journal of Petrology. 